\title{
Recommendations on methods for the detection and control of biological pollution in marine coastal waters
}

\author{
Sergej Olenin ${ }^{\mathbf{a}, \mathbf{b}, *}$, Michael Elliott ${ }^{\mathbf{c}}$, Ingrid Bysveen ${ }^{\mathbf{d}}$, Phil F. Culverhouse ${ }^{\mathbf{e}}$, Darius Daunys ${ }^{\mathbf{a}}$, George \\ B.J. Dubelaar ${ }^{f}$, Stephan Gollasch ${ }^{\mathrm{g}}$, Philippe Goulletquer ${ }^{\mathrm{h}}$, Anders Jelmert', Yuri Kantor ${ }^{\mathrm{j}}$, Kjersti \\ Bringsvor Mézeth ${ }^{\mathbf{b}}$, Dan Minchin ${ }^{\mathbf{k}, \mathbf{a}}$, Anna Occhipinti-Ambrogi', Irina Olenina ${ }^{\mathbf{a}, \mathbf{b}}$, \\ Jochen Vandekerkhove ${ }^{\mathrm{m}}$
}

\footnotetext{
${ }^{\text {A }}$ Coastal Research and Planning Institute, Klaipeda University, Lithuania

${ }^{\mathrm{b}}$ Uni Environment, Thormoelhensgate 49B, 5008 Bergen, Norway

${ }^{c}$ Institute of Estuarine \& Coastal Studies, University of Hull, Hull HU6 7RX, UK

${ }^{\mathrm{d}}$ Directorate for Nature Management, Trondheim, Norway

e Centre for Robotics \& Neural Systems, University of Plymouth, Plymouth PL4 8AA, UK

${ }^{f}$ CytoBuoy b.v., The Netherlands

${ }^{\mathrm{g}}$ GoConsult, Hamburg, Germany

h Ifremer, Scientific Strategy Division, Nantes, France

Institute of Marine Research, P.O. Box 1870, Nordnes, 5817 Bergen, Norway

${ }^{j}$ A.N. Severtzov Institute of Ecology and Evolution, Moscow, Russia

${ }^{\mathrm{k}}$ Marine Organism Investigations, 3 Marina Village, Ballina, Killaloe, Co Clare, Ireland

' Department of Earth and Environmental Sciences, University of Pavia, Italy

${ }^{\mathrm{m}}$ European Commission, Joint Research Centre, Institute for Environment and Sustainability, Ispra, Italy
}

*: Corresponding author : Sergej Olenin, Tel.: +370 46398847 ; fax:+370 46398845

email address : sergej@corpi.ku.It

\begin{abstract}
:
Adverse effects of invasive alien species (IAS), or biological pollution, is an increasing problem in marine coastal waters, which remains high on the environmental management agenda. All maritime countries need to assess the size of this problem and consider effective mechanisms to prevent introductions, and if necessary and where possible to monitor, contain, control or eradicate the introduced impacting organisms. Despite this, and in contrast to more enclosed water bodies, the openness of marine systems indicates that once species are in an area then eradication is usually impossible. Most institutions in countries are aware of the problem and have sufficient governance in place for management. However, there is still a general lack of commitment and concerted action plans are needed to address this problem. This paper provides recommendations resulting from an international workshop based upon a large amount of experience relating to the assessment and control of biopollution.
\end{abstract}

\section{Highlights}

We summarize the results of an international workshop on marine biopollution. We recommend science-based information support for bioinvasion management. We outline types of bioinvasion monitoring and consider topical research needs. We emphasize the role of taxonomy training and public involvement. Biopollution should be treated in the same way as any other type of pollution.

Keywords : Biological invasion; Research needs; Monitoring; Management 


\section{Introduction}

Marine biological invasions are increasingly changing coastal biota. They can alter ecosystem functioning and often seriously affect an economy and human health, and so remain high on the environmental management agenda (Lodge et al., 2006; CBD, 2004; European Commission, 2008a; Pyšek, Richardson, 2010). The bioinvasion problem in marine environment has recently been described as an exogenic unmanaged pressure, i.e. a pressure emanating from outside a system and with the potential to change or damage marine systems and the human uses of those systems to which we have to respond (Elliott, 2011). As long as we have a need to move materials around the globe, we have a limited capacity to control the cause of the pressure yet we should respond to the consequences. Not all non-indigenous species (NIS), which were deliberately or accidentally introduced by humans outside their native range, will necessarily cause harm to the environment. However, it is very difficult to predict which of NIS introductions may result in detrimental effects on environmental quality which result in changes to the biological, chemical and/or physical properties of an invaded ecosystem. Despite this, environmental managers are mainly interested in those species that have significant impacts on the environment, quality of life, economy and/or human health. 
While plans for the management of NIS, in general, and marine introduced species in particular, have been and are being developed (e.g. Lodge et al. 2006; European Commission, 2008a; Johnsen et al., 2011), the implementation of such plans would benefit greatly from a synthesis of international knowledge. Accordingly, an international workshop Indicator based methods to assess and map biological pollution in the coastal waters of Norway" was arranged in Bergen, May 27-29, 2009 with the objective to consolidate the existing international knowledge on methods of assessment and mapping biological pollution (biopollution) in marine coastal waters. This paper gives the recommendations from the workshop summarising modern methods for early detection and mapping of NIS, approaches for the assessment of consequences of biopollution and information needs for supporting marine bioinvasion management.

\section{Conceptual framework}

The terminology of invasion ecology yet is not well established due to the rapid development of this discipline. Therefore, to ensure consistency and for the sake of simplicity the following definitions, derived from Olenin et al. (2010), are used throughout the text.

\section{$\underline{\text { Non-indigenous species }}$}

(synonyms: alien, exotic, non-native, allochthonous) these are species or subspecies or lower taxa introduced outside of their natural range (past or present) and outside of their natural dispersal potential. This includes any part, gamete or propagule of such species that might survive and subsequently reproduce. It also includes hybrids between an alien species and an indigenous species, fertile polyploid organisms and artificially hybridized species irrespective of their natural range or dispersal potential (Council Regulation, 2007). Their presence in the given region is due to intentional or unintentional introduction resulting from human activities, or they have arrived there without the help of people from an area in which they are alien.

Increasingly, global warming will become a cause of species distribution change. Despite this, natural changes in distribution ranges (e.g. due to climate change or dispersal by ocean currents) do not qualify a species as being a non-indigenous one. However, the secondary spread of non-indigenous species from the area(s) of their first arrival could occur without further human involvement due to dispersal by natural means.

$\underline{\text { Invasive alien species (IAS) }}$ 
are a subset of established NIS which have spread, are spreading or have demonstrated their potential to spread elsewhere, and have an adverse effect on biological diversity, ecosystem functioning, socio-economic values and/or human health in invaded regions. Species of unknown origin which cannot be ascribed as being native or alien are termed cryptogenic species (sensu Carlton, 1996), some of these also can cause significant impacts. They may also demonstrate invasive characteristics and should be included in IAS assessments.

\section{$\underline{\text { Biological pollution }}$}

Often the impact of IAS has been interpreted as a decline in ecological quality resulting from changes in biological, chemical and physical properties of an aquatic ecosystem. These changes include (but are not confined to): local elimination or extinction of sensitive and/or rare species; alteration of native communities; algal blooms or other outbreak formations and massive population expansions; modification of substratum conditions including shore zones; alteration of oxygen and nutrient concentration, $\mathrm{pH}$ and transparency of the water and accumulation of synthetic pollutants. Biological pollution is defined as the adverse impacts of invasive alien species at the level that disturb ecological quality by effects on one or more levels of biological organisation: an individual (such as internal biological pollution by parasites or pathogens), a population (by genetic change, i.e. hybridization), a community (by structural shift), a habitat (by modification of physical-chemical conditions), or/and an ecosystem (by alteration of energy and organic material flow) (Elliott 2003; Olenin et al. 2010). The biological and ecological effects of biopollution may also cause adverse economic consequences.

\section{Pathway}

A pathway is the route a NIS species takes to enter or spread through a non-native ecosystem. Each pathway may have a number of vectors. A vector is a transfer mechanism and is the physical means by which species are transported from one geographic region to another. Several vectors within a pathway may be involved in a transmission, e.g.: shipping (a pathway) includes such vectors as ship ballast water, hull fouling, anchor chains, etc. (Minchin et al. 2009).

\section{Propagule pressure}

Propagule pressure can be defined as the quality, quantity and frequency of invading organisms (Johnston et al. 2009 and references therein). This is a number of individuals of a NIS released into a region to which they are not native multiplied by the number of discrete 
release events. As the number of releases or the number of individuals released increases, more likely to survive, whereas species introduced in small numbers with only a few release events are more likely to go extinct (Lockwood et al. 2005).

\section{$\underline{\text { Marine bioinvasion process and management options }}$}

The invasion process includes several consecutive stages which must be taken into account while planning and implementing management options (Wittenberg \& Cock 2001; Lodge et al., 2006; Minchin et al., 2009; Davis 2009). The number of species involved in the pathway is always greater than the number of species which managed to survive transport and establish a population (Figure 1). Establishment is defined here as living long enough to be able to reproduce (sensu Davis 2009) and provide recruiting generations. Prevention of introductions involving inspection, exclusion and/or primary treatment, is the first and most cost-effective option, which is only possible early in the process, before a species arrives at the point of entry. Usually, prevention is to be applied in areas beyond national jurisdiction, i.e. Preborder and so its applicability depends on international legislation, e.g. Ballast Water Management Convention (IMO, 2004), or agreements, e.g. ICES Code of Practice on the Introductions and Transfers of Marine Organisms (ICES, 2004). On arrival, Rapid response (incl. disinfection, eradication, quarantine) may prevent further invasion provided that hub monitoring is in place which ensure early detection of a NIS. Once a NIS is established its eradication is costly and rarely practical but where it is feasible would depend on a rapid response by managers. Once a species is in the expansive phase eradication is unlikely leaving a different suite of, very often less effective and more costly management options: i.e., containment (restricting spread and keeping an IAS within a certain geographic area), control (long-term reduction in abundance by mechanical, chemical, biological and other methods) and mitigation (adaptation and bearing the costs). As a rule these are Post-border management options whose success depends on sound scientific advice, political motivation and resources. Finally, it should be recognised that secondary spread from an area of primary introduction due to natural dispersal and/or human mediated vectors may obstruct an effective management option. Despite this, we emphasise here that the size, openness and degree of connectivity of marine systems present the greatest obstacles to the detection and eradication of species once introduced to an area. 


\section{Information support}

More advanced information systems on NIS are needed to support bioinvasion management. Bioinvasion studies lack being more analytical and predictive because of uncertainties about vectors involved in the transportation process (Minchin, 2007a), numbers of established and spreading NIS, propagule pressure (Johnston et al., 2009), biological traits of invaders (Karatayev et al., 2009) and their environmental tolerance limits (Olyarnik et al., 2009), their functional role (Crooks, 2009) and the impacts on environment, economy and human health (Olenin et al., 2007).

\section{Recommendation 1}

Ensure science-based information support for bioinvasion management. Systematically collect, summarize and analyze information on:

- Pathways and vectors (their availability, seasonal patterns and longterm trends, level of confidence while ascribing transfer of species to a particular pathway);

- Propagule pressure (number of NIS, number of individuals involved in a pathway, and frequency of pathway movements);

- Prioritise sites and conditions for potential entry of NIS. Environmental matching between the source and recipient areas (including data on sea currents to estimate probability of the second spread);

- Biological traits of introduced species and their environmental tolerance limits;

- Assumed environmental consequences of bioinvasions (impacts of IAS on e.g. native biodiversity and ecosystem functioning);

- Assumed economic and social consequences of bioinvasions including impacts on human health;

- Feasibility and cost of eradication and/or management.

Make this information available and understandable for decision makers and stakeholders at international, regional, national and local levels. 
Most of the existing NIS databases have no information about the bioinvasion impacts, or this information is just anecdotal. Moreover, in most cases there is no structure to accommodate data on impacts (e.g. on environment, public health, public well being and quality of life, uses of marine areas and economy) in a standardized way. Furthermore, the inclusion of assumed criteria is necessary given the high degree of uncertainty amongst vectors and also can be regarded as contributing to the precautionary approach inherent in all other types of pollution control.

\section{Recommendation 2}

- Make databases on NIS a multipurpose tool: useful for research and practical for management. The tenet "nice-to-know” (driven by scientific curiosity only) should be changed to the principle "need-toknow" (driven by management needs).

- Further develop the functionality of the existing NIS databases by including information and relevant search functions on NIS biological traits, their environmental tolerance limits and impacts on native biodiversity, ecosystem functioning, economy and public health.

- Promote interoperability among national, regional and international databases

Furthermore, it is the impacts of alien invasive species that make the problem of bioinvasion so important for managers: they need to know why public and/or shipping/ports industry money should be spent to prevent new introductions and also to know what is the feasibility of control measures. Our collective experience indicates that although ecological considerations are upmost in our minds, at this time of financial difficulties then focussing the discussion on the economic consequences has an even greater resonance with policy makers.

\section{Recommendation 3}


- Convey information on the impacts in a standardized way to make possible objective comparisons between different species and different ecosystems. Make this information available for international use, as countering bioinvasion requires internationallycoordinated actions.

- Use the best available scientific knowledge (e.g. objective bioinvasion impact assessment methods) to produce a "target list" of potentially harmful species which are not yet introduced to the region of concern.

\section{Research needs}

\section{$\underline{\text { Selection of study sites }}$}

The proper estimation of the scope of the problem and the determination and implementation of adequate management measures requires a good knowledge on introduction pathways, the rate of spread and distribution patterns of NIS and assessment of their environmental and economic impacts. These processes cannot be examined equally in the countries with an extensive coastal marine environment; therefore careful selection of the representative study sites and adequate research methods should be performed prior to the start of any large scale field campaigns on mapping of NIS.

\section{Recommendation 4}

- Develop the criteria for sites at risk of certain species introductions, and indicate these as ,probable ${ }^{e,}$, possible ${ }^{\mathrm{ee}}$ and ,not likely ${ }^{e е}$;

- Use conventional maps and GIS to identify main study sites; from these take a subset and monitor a representative set of habitats at each. Use these sites as surrogates for all sites, ensuring that the subset adequately covers the main coastal types and range of human activities.

- Perform a cost-benefit analysis to achieve the best coverage of the study sites. 
The selection of the study sites should be based on the analysis of most likely entry" points/hubs where introductions are likely to arrive and hot spots" containing elevated numbers of NIS, such as ballast water discharge areas, docks, marinas and aquaculture sites with stock movements by undertaking rapid surveys for targeted species (Ashton et al., 2006; Minchin 2007b). Off-shore windfarms and any other hard structures such as rigs/harbours and shipwrecks may form important stepping stones for the incremental spread for some groups of NIS. In addition, areas of special interest or concern, such as nature conservation sites, should be included in lists of the study sites.

\section{Recommendation 5}

- Develop the rapid assessment technique using e.g. floating pontoons at fish farm and marina sites as a practical indicator-based method for undertaking surveys of non-indigenous sessile species and their associates.

\section{$\underline{\text { Monitoring }}$}

It is important to realize, especially in times of financial stringency, that monitoring can never cover all spatial and time scales and thus need to be supplemented by information from other sources, including, e.g., the general public, without loosing the quality of the records. In many countries monitoring takes place by separate bodies for different purposes. These initiatives need to be coordinated to provide a more cost-effective monitoring programme. Different types of NIS monitoring may be applied according to the purposes and further uses of the collected information (see also Elliott 2011 regarding the monitoring types and criteria for indicators used in monitoring):

- Surveillance monitoring, usually conducted by regulatory bodies, is aimed at early detection of new introductions and inspection of spread of established NIS;

- Compliance monitoring, of the recording of IAS against pre-defined guidelines, objectives and standards.

- Operational monitoring follows the polluter pays" principle and is aimed at passing on the costs for remediation to the party responsible for 
producing pollution responsible and for the cause of the damage to the natural environment and resource users;

- Investigative or diagnostic monitoring is focused on detecting the cause of impacts of NIS (-Đoes a NIS really pose the problem? What will change if we take measures?").

To our knowledge, the polluter pays" principle so far has rarely been applied to biological pollution cases, at least in the marine environment, although the compliance monitoring is an important instrument in the Ballast Water Management Convention of the International Maritime Organization, the United Nations body to deal with shipping (Gollasch et al. 2007).

Recommendation 6
- Conduct port sampling studies to undertake bioinvasion risk
assessments with the aim of exempting suitable and responsible
vessels from ballast water management requirements (in line with
the relevant Guidelines of the IMO Ballast Water Management
Convention).

There is a broad suite of methods which may be used for different types of monitoring, ranging from traditional biological surveys for plankton, benthos, fish, etc, involved in fisheries research, to specific techniques, e.g. the deployment of fouling panels at entry" points or hot spots" where settling NIS may be expected. Special attention should be paid to the development and application of modern cytometric approaches, such as molecular barcoding and individual particle analysis and imaging devices (Paul et al. 2007, Dubelaar et al. 2007), especially for the early detection of new introductions. Automated systems (e.g. Culverhouse et al. 2005; Malkassian et al. 2011) may pick up unfamiliar biological shapes that can lead to a more detailed study into the taxonomy of such \#nusual" objects. The need for a high throughput of samples by such instruments is an important consideration when taking into account low abundance NIS.

\section{Recommendation 7}


- Develop an in-situ continuous monitoring capacity that initially images aliquots of sea water and rejects images of low-risk objects. This ,pre-filteringe identification method can reduce human sampling time. Such a system can then be improved to reduce the false positive and false negative identification rates. A managed webbased image database should be developed that acts a repository for images of identified NIS, together with metadata reflecting the scale of the object, its location, depth and date of image collection, and collector.

\section{$\underline{\text { Risk assessment }}$}

The study of invasions in coastal marine systems, although now a rapidly growing ecological discipline, began a little more than three decades ago. The scientific interest is mostly driven by practical needs due to some serious ecological and economical consequences of bioinvasions. It has not been possible to predict with absolute certainty all consequences that result from intentional or unintentional introductions. For example, it was considered unlikely that the Pacific oyster (Crassostrea gigas) would reproduce in the cool North Sea waters; but high density populations have now occurred in this region due to successful recruitment as a result of localized warmer conditions and physiological adaptability (Reise and van Beusekom, 2008).

\section{Recommendation 8}

- Develop, using international co-operation, criteria for determining which species are invasive, or potentially invasive, which should not be permitted entry.

- The use of native species must be prioritized for further aquaculture projects, where practicable. The ICES Code of Practice should be followed in cases where NIS are to be introduced for culture.

\section{$\underline{\text { Fundamental ecological research }}$}

As with all types of pollution, the problem of the biological pollution" requires multidisciplinary solutions, involving not only biological/ecological but also technical and 
socio-economic aspects. Bioinvasion management should therefore be based on the results of interdisciplinary research.

Recommendation 9
- Link natural and social science research regarding the effects of
adherence to international agreements to prevent the influx of
invasive species.

In addition to practical interests regarding the biological invasions, they also provide a unique opportunity for fundamental ecological research as almost all biological invasions may be considered as unplanned in situ experiments (Rilov, Crooks, 2009). The studies of those fundamental ecological phenomena may range from genetic change and hybridization to adaptations of living organisms and communities, alterations in biochemical cycles (Zaiko et al., 2010) due to introduction of new functional groups (Olenin, Leppäkoski, 1999), habitat change (Wallentinus, Nyberg, 2007), predator-prey interactions with native species (Rilov, 2009) and ecosystem functioning (Grosholz, Ruiz, 2009). Hence there is the need to assess structure and functioning of systems as modified by IAS and over spatial (near-field, _farfield') and temporal (short, medium and long term) scales. Infrastructure capacity-building aimed at high frequency in situ and ship based monitoring tools and data integration, including modern technologies, should be considered.

\section{Recommendation 10}

- Conduct research on the effects and consequences of controlling (or being unable to control) the impact of IAS or of working towards eradication where possible and practicable.

- Study the changes to the functioning of marine ecosystems subjected to an impact of invasive alien species. 


\section{Recommendation 11}

- Explore the genetic structures of cultured populations distributed along the coasts to identify exchange of genotypes. Employ molecular genetic methods to trace the origin of NIS.

- Create the bank of bar-coding sequences of introduced NIS and NIS potentially expected in the areas of surveys

$\underline{\text { Biopollution and environmental status of marine waters }}$

The environmental status of marine waters is traditionally being evaluated taking into account the effects of various forms of chemical pollution, eutrophication, habitat destruction and overexploitation. However, the bioinvasion impacts (i.e. biopollution) may also have pronounced effects on the environment, which may even surpass the impacts of other stressors, and therefore should be considered while undertaking environmental assessments. It is of note that one of the Good Environmental Status descriptors in the European Marine Framework Strategy Directive specifically addresses the bioinvasion problem: Aonindigenous species introduced by human activities are at levels that do not adversely alter the ecosystem" (European Commission, 2008b; Borja et al., 2010). The key term - levels that do not adversely alter the ecosystems" was described as the absence or minimal level of biological pollution (Olenin et al., 2010) although as yet we may not know what these levels are. Increasingly, the consequences of human-induced problems need to be considered on fundamental and final ecosystem services and societal benefits, again focusing on both the ecological and economic repercussions of AIS (Atkins et al 2011). Additional scientific and technical tools are required for developing potentially useful indicators, such as bio-pollution indices (European Commission, 2010 ), especially in the case of Europe, where impacts of IAS are a major concern that may prevent achieving Good Environmental Status (European Commission, 2008b).

\section{Recommendation 12}

- Conduct studies to assess how invasive species affect marine ecosystem services and socio-economic benefits. 
- Quantify economic losses caused by marine bioinvasions and any benefits gained due to the introductions of non-native species.

- Develop a bioinvasion impact assessment methodology enabling quantification and comparative analysis of the consequences of NIS introductions. Integrate this methodology into an assessment system of overall marine environmental status.

\section{Global warming and bioinvasions}

Global warming promotes the expansion towards higher latitudes of NIS and increases risks of introductions originating from warmer climate regions (Occhipinti-Ambrogi, 2007), for example by means of ballast water transfer. Intensification of human activities in sub-Arctic and Arctic areas, including a seasonal opening of Northern Sea Routes, is likely to increase the risk of new bioinvasions. These processes may cause significant changes in the marine biodiversity on both costs of the North Atlantic Ocean.

\section{Recommendation 13}

- Explore the effects of climate change on introduced NIS in the marine environment.

- Examine scenarios of environmental change and their likely consequences to identify new invaders expanding their range from other regions.

\section{Public awareness and education}

It is important to raise the public awareness on introduced species, as well as to develop systematic mapping programmes and maintain an appropriate taxonomic expertise. It is necessary to reinforce training in both traditional and molecular taxonomy in universities so as to have the ability to recognize marine introductions. It is of increasing concern that traditional taxonomic education now has a less-important role in university education than previously the case. It is of note that new findings of NIS have often been made by the general public (students, SCUBA divers, yachtsmen, aquaculture producers, bird watchers, amateur 
naturalists, etc) thus showing that natural history' has a role to play in this field. Discoveries of invasive species in new localities, by using public and private monitoring programmes, should be readily available on the internet.

\section{Recommendation 14 \\ - Develop a strategy to involve the general public in monitoring and reporting of NIS in coastal marine environments.}

\section{Conclusions}

In essence, we emphasise that it is necessary to treat biopollutants in the same way as any other pollutant whereby a sustainable management policy has to follow the so-called 7-tenets (see Table 1) (adapted from Elliott et al., 2007; Mee et al. 2008, Elliott 2011). These are merely re-emphasising the existing practices in many countries but are required as main messages for policy-makers; for example, many countries have in place the required governance mechanisms. It is of note that North American governance considers bioinvasion problem and control of biopollutants through the Oceans Acts, Environmental Protection Acts and Clean Water Acts in the US and Canada. In Europe IAS are included in EU Marine Strategy Framework Directive, they are considered in European regional seas and some national action plans but yet an overall concerted and integrated action is needed.

\section{Recommendation 15}

- Treat biological pollution in the same way as other types of pollution, such as oil spills, and develop contingency plans for marine NIS introductions, including an efficient rapid response on findings of a newly introduced species where practicable.

\section{Acknowledgements}

The workshop was supported by the Research Council of Norway (project No. 190363), Bergen University Foundation and Unifob AS (now Uni Research AS), and arranged by the Uni Environment. We would like to thank Ann-Lisbeth Agnalt, Lis Lindal Jørgensen, Knut E. 
Jørstad, Vivian Husa, Ståle Knudsen, Karsten Reise, Tracy McCollin, Karin Margrethe Vedø, Kjersti Sjøtun, and Inger Wallentinus for fruitful discussions at the workshop. Further work on manuscript was supported by the EC 7th framework program (FP7) a Collaborative Project MEECE (Marine Ecosystem Evolution in a Changing Environment, No 212085) for I.

Olenina and by a FP7 Project VECTORS (Vectors of Change in Oceans and Seas Marine Life, Impact on Economic Sectors, No. 266445) for S. Olenin, M. Elliott, A. OcchipintiAmbrogi, S. Gollasch and D. Minchin.

\section{References}

Atkins, J.P., Burdon, D., Elliott, M., Gregory, A.J., 2011. Management of the Marine Environment: Integrating Ecosystem Services and Societal Benefits with the DPSIR Framework in a Systems Approach. Marine Pollution Bulletin, 62(2): 215-226.

Borja, A., Elliott, M., Carstensen, J., Heiskanen, A.-S., van de Bund, W., 2010. Marine management - Towards an integrated implementation of the European Marine Strategy Framework and the Water Framework Directives. Marine Pollution Bulletin 60 (2010) 21752186

Carlton, J.T., 1996. Biological invasions and cryptogenic species. Ecology 77: 1653-1655.

CBD, 2004. Secretariat of the Convention on Biological Diversity. Solutions for sustainable mariculture - avoiding the adverse effects of mariculture on Biological diversity. Report of the Ad hoc Technical Expert Group on mariculture. CBD Technical Series No12, 52p.

Council Regulation, 2007. EC, No 708/2007 of 11 June 2007 concerning use of alien and locally absent species in aquaculture.18.7.2007 Official Journal of the European Union L 168 of 28.6.2007

Crooks, J.A. 2009. The Role of exotic Marine Ecosystem Engineers. In: G. Rilov, J.A. Crooks (Eds.) Biological Invasions in Marine Ecosystems Ecological, Management, and Geographic Perspectives. Series: Ecological Studies, 204 (XXVI): Springer-Verlag: 215-238.

Culverhouse, P.F. , Williams, R., Simpson, B. , Gallienne, C. , Reguera, B. , Cabrini, M. , Fonda-Umani, S. , Parisini, T. , Pellegrino, FA, Pazos, Y. , Wang, H. , Escalera, L. , Moroño, A. , Hensey, M. , Silke, J. , Pellegrini, A. , Thomas, D. , James, D. , Longa, MA, Kennedy, S. and Punta, G. del, 2006. HAB Buoy: a new instrument for in situ monitoring and early warning of harmful algal bloom event. African Journal of Marine Science, 28: 2, $245-250$ 
Dubelaar, G.B.J., Casotti, R., Tarran, G.A., Biegala, I.C., 2007. Phytoplankton and their Plant Cells. Wiley-VCH Verlag GmbH \& Co. KGaA, Weinheim.

Elliott, M., 2003. Biological pollutants and biological pollution - an increasing cause for concern. Marine Pollution Bulletin, 46, 275-280.

Elliott, M., 2011. Marine science and management means tackling exogenic unmanaged pressures and endogenic managed pressures - a numbered guide. Marine Pollution Bulletin, 62: 651-655.

Elliott, M., Burdon, D., Hemingway, K.L., Apitz, S., 2007. Estuarine, Coastal and Marine Ecosystem Restoration: confusing management and science - a revision of concepts. Estuarine, Coastal \& Shelf Science 74: 349-366.

European Commission, 2008a. Directive 2008/56/EC of the European Parliament and of the Council of 17 June 2008 establishing a framework for community action in the field of marine environmental policy (Marine Strategy Framework Directive). Official Journal of the European Union L164, 19-40.

European Commission, 2008b. Commission of the European Communities. Brussels, 3.12.2008 SEC(2008) 2887 Commission staff working document. Annex to the Communication from the Commission to the Council, the European Parliament, the European Economic and Social Committee and the Committee of the Regions towards an EU strategy on invasive species impact assessment.

European Commission, 2010. Commission Decision 2010 of 1 September 2010 on criteria and methodological standards on good environmental status of marine waters. L 232/14 Official Journal of the European Union 2.9.2010

Gollasch, S., David, M., Voigt, M., Dragsund, E., Hewitt, C., Fukuyo, Y., 2007. Critical review of the IMO International Convention on the Management of Ships' Ballast Water and Sediments. In: Hallegraeff, G.M. (ed.): Harmful Algae 6, 585-600.

Grosholz, E.D., Ruiz, G.M., 2009. Multitrophic Effects of Invasions in Marine and Estuarine Systems. In: G. Rilov, J.A. Crooks (Eds.) Biological Invasions in Marine Ecosystems Ecological, Management, and Geographic Perspectives. Series: Ecological Studies, 204 (XXVI): Springer-Verlag: 305-324. 
ICES, 2004. ICES Code of Practice on the Introductions and Transfers of Marine Organisms.

Available at http://www.ices.dk/reports/general/2004/icescop2004.pdf

IMO, 2004. International Maritime Organization. International Convention for the Control and Management of Ships' Ballast Water and Sediments. Available at http://www.imo.org Johnsen, T., Sandlund, O.T., Often, A., Jelmert, A., Hobæk A., 2011. Kartlegging og overvåking av fremmede skadelige arter i Norge. Niva rapport no OR-5969 59pp. ISBN 97882-577-5704-5 (In Norwegian).

Johnston, E.L., Piola, R.F., Clark, G.F. 2009. The Role of Propagule Pressure in Invasion Success. In: G. Rilov, J.A. Crooks (Eds.) Biological Invasions in Marine Ecosystems Ecological, Management, and Geographic Perspectives. Series: Ecological Studies, 204 (XXVI): Springer-Verlag: 134-151.

Karatayev A.Y., Burlakova L.E., Padilla D.K., Mastitsky S.E., Olenin S. 2009. Invaders are not a random selection of species. Biological Invasions, 11 (9): 2009-2019

Lockwood, J.L., Cassey, P., Blackburn, T., 2005. The role of propagule pressure in explaining species invasions. Trends in Ecology \& Evolution, 20: 223-228.

Lodge, D.M., Williams, S., MacIsaac, H.J., Hayes K.R. et al., 2006. Biological invasions: recommendations for U.S. policy and management. Ecological Applications, 16(6): 20352054.

Malkassian, A., Nerini, D., van Dijk, M. A., Thyssen, M., Mante, C., Gregori, G., 2011. Functional analysis and classification of phytoplankton based on data from an automated flow cytometer. Cytometry Part A, 79A: 263-275.

Mee, L.D., Jefferson, R.L., Laffoley, D.A, Elliott, M., 2008. How good is good? Human values and Europe‘s proposed Marine Strategy Directive. Marine Pollution Bulletin, 56: 187204.

Minchin, D. 2007. Aquaculture and transport in a changing environment: overlap and links in the spread of alien biota. Marine Pollution Bulletin, 55: 302-313.

Minchin, D. 2007. Rapid coastal survey for targeted alien species associated with floating pontoons in Ireland. Aquatic Invasions, 2(1): 63-70.

Minchin, D., Gollasch, S., Cohen, A.N., Hewitt, C.L., Olenin, S., 2009. Characterizing Vectors of Marine Invasion. In: G. Rilov, J.A. Crooks, Jeffrey A. (Eds.). Biological Invasions 
in Marine Ecosystems Ecological, Management, and Geographic Perspectives. Series:

Ecological Studies, 204 (XXVI): 109-116.

Occhipinti-Ambrogi A., Galil B., 2004. A uniform terminology on bioinvasions: a chimera or an operative tool? Marine Pollution Bulletin, 49: 688-694.

Occhipinti-Ambrogi, A. 2007. Global change and marine communities: alien species and climate change. Marine Pollution Bulletin 55: 342- 352

Olenin S., Minchin D., Daunys D., 2007. Assessment of biopollution in aquatic ecosystems. Marine Pollution Bulletin, 55: 379-394.

Olenin, S., Alemany, F., Cardoso, A.C., Gollasch, S., Goulletquer, P., Lehtiniemi, M., McCollin, T., Minchin, D., Miossec, L., Occhipinti Ambrogi, A., Ojaveer, H., Jensen, K.R., Stankiewicz, M., Wallentinus, I. \& Aleksandrov, B., 2010. Marine Strategy Framework Directive - Task Group 2 Report. Non-indigenous species. EUR 24342 EN. ISBN 978-92-7915655-7. ISSN 1018-5593. DOI 10.2788/87092. Luxembourg: Office for Official Publications of the European Communities. 44 pp.

Olenin, S., Leppäkoski, E. 1999. Non-native animals in the Baltic Sea: alteration of benthic habitats in coastal inlets and lagoons. Hydrobiologia, 393: 233-243.

Olyarnik, S.V., Bracken M.E.S., Byrnes J.E., Hughes, R., Hultgren, K.M., Stachowicz, J.J., 2009. Ecological Factors Affecting Community Invasibility. In: G. Rilov, J.A. Crooks (Eds.) Biological Invasions in Marine Ecosystems Ecological, Management, and Geographic Perspectives. Series: Ecological Studies, 204 (XXVI): Springer-Verlag: 215-238.

Paul, J., Scholin, C., van den Engh, G., Perry M.J., 2007. In situ Instrumentation. Oceanography 20, 2: 70-78.

Pyšek, P., Richardson, D.M. 2010. Invasive Species, Environmental Change and Management, and Health. Annual Review of Environment and Resources, 35:25-55

Reise, K., Beusekom, J.E.E. van, 2008. Interactive effects of global and regional change on a coastal ecosystem. Helgoland Marine Research, 62: 85-91.

Rilov, G., 2009. Predator-Prey Interactions of Marine Invaders. In: G. Rilov, J.A. Crooks (Eds.) Biological Invasions in Marine Ecosystems Ecological, Management, and Geographic Perspectives. Series: Ecological Studies, 204 (XXVI): Springer-Verlag: 261-285. 
Rilov, G., Crooks, J.A., 2009.Marine Bioinvasions: Conservation Hazards and Vehicles for Ecological Understanding. In: G. Rilov, J.A. Crooks (Eds.) Biological Invasions in Marine Ecosystems Ecological, Management, and Geographic Perspectives. Series: Ecological Studies, 204 (XXVI): Springer-Verlag: 3-11.

Wallentinus, I., Nyberg, C.D., 2007. Introduced marine organisms as habitat modifiers. Marine Pollution Bulletin, 55(7-9): 323-332

Wittenberg, R., and Cock, M.J.W. (eds.), 2001. Invasive Alien Species: A Toolkit of Best Prevention and Management Practices. CAB International, Wallingford, Oxon, UK, 228 pp. Zaiko A., Paškauskas R., Krevš A. 2010. Biogeochemical alteration of the benthic environment by the zebra mussel Dreissena polymorpha (Pallas). Oceanologia, 52(4): 649667. 
Table 1 The 7-tenets for sustainable marine management as applied to AIS (adapted from Elliott 2011)

\begin{tabular}{|c|c|}
\hline 7-tenets & Relevance to biopollutants \\
\hline $\begin{array}{l}\text { - ecologically/environmentally } \\
\text { sustainable }\end{array}$ & $\begin{array}{l}\text { Will the control efforts of the biopollutants achieve } \\
\text { the desired ecological effect, will it prevent natural } \\
\text { ecological change? }\end{array}$ \\
\hline - economically viable & $\begin{array}{l}\text { Are there the financial and labour resources to } \\
\text { achieve control? Can the monitoring and } \\
\text { eradication, if necessary, be paid for? What are the } \\
\text { economic repercussions of not tackling the } \\
\text { problem? }\end{array}$ \\
\hline - technologically feasible & $\begin{array}{l}\text { Do we have control methods available? Can we } \\
\text { eradicate or even prevent the spread of the } \\
\text { organisms using present techniques? Will any of } \\
\text { the eradication and control techniques produce } \\
\text { further adverse effects? }\end{array}$ \\
\hline - socially desirable/tolerable & $\begin{array}{l}\text { Does society agree that this is such a large problem } \\
\text { that they are willing to devote the necessary } \\
\text { resources (away from other spending priorities) or } \\
\text { does society tolerate the absence of action? }\end{array}$ \\
\hline - administratively achievable & $\begin{array}{l}\text { Do we have the right regulatory bodies with } \\
\text { sufficient resources to control the biopollutants. Do } \\
\text { they have the necessary skills, expertise and } \\
\text { personnel? }\end{array}$ \\
\hline - legally permissible & $\begin{array}{l}\text { Do we have sufficient laws, agreements, treaties } \\
\text { and other statutory instruments to allow the } \\
\text { regulatory bodies and other authorities to control } \\
\text { the biopollutants? Will these be enforced for } \\
\text { industry, ports and navigation? }\end{array}$ \\
\hline - politically expedient & $\begin{array}{l}\text { Is there political will to control these organisms, } \\
\text { has public and scientific opinion been } \\
\text { communicated to politicians and policy makers? }\end{array}$ \\
\hline
\end{tabular}




\section{Figures}

Figure 1. Stages of an invasion process (the size of shapes indicates a relative number of propagules involved at each stage); pre-border (prevention), at border (rapid response) and post border (control, containment and mitigation) management options, and related research activities. (Explanation in text).

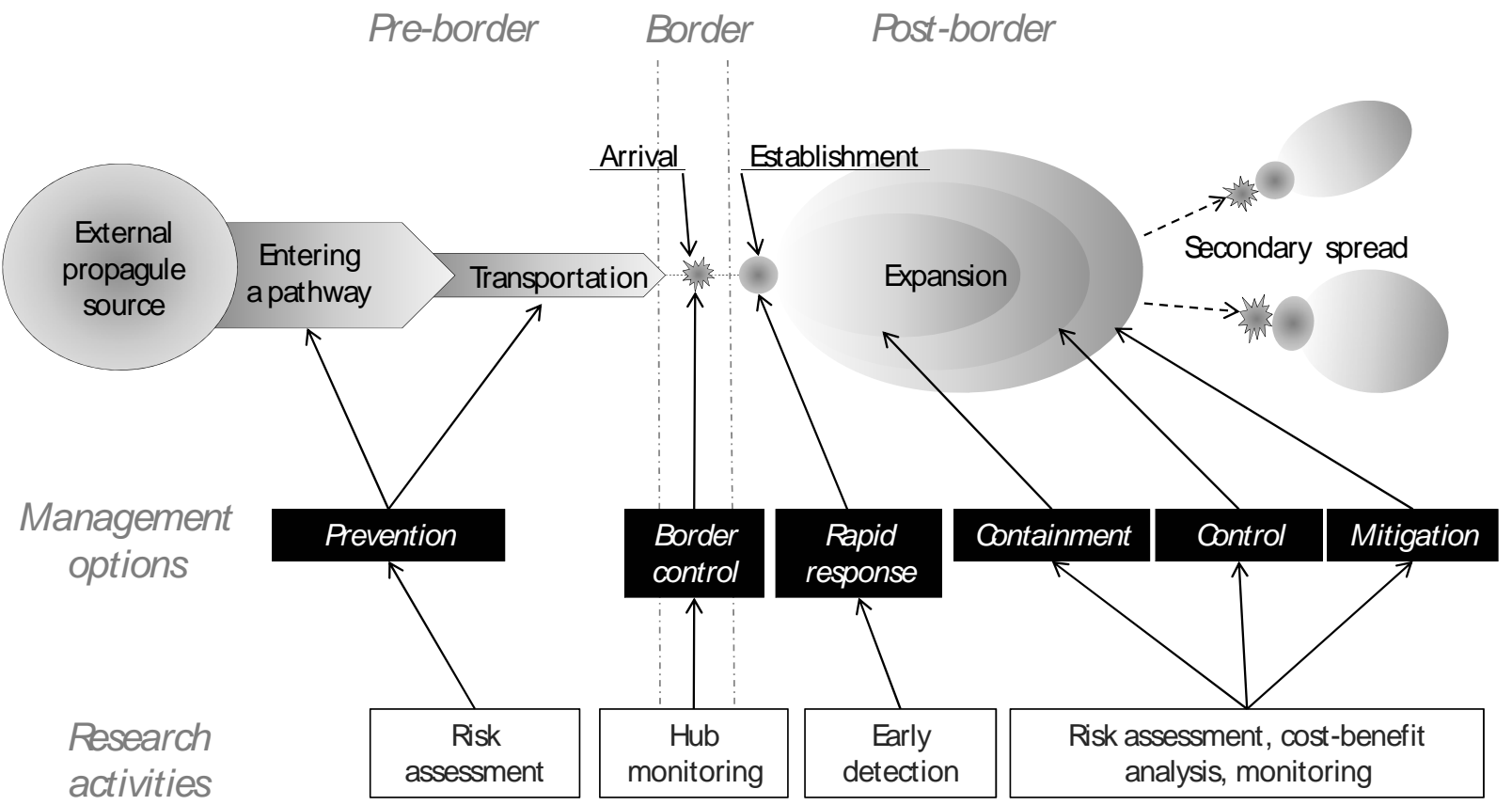

